\title{
CORPORATE GOVERNANCE IN FOUNDERS' CONTROLLED COMPANIES
}

\author{
Maria ALUCHNA \\ Warsaw School of Economics \\ Al. Niepodleglosci 162, 02-554 Warsaw, Poland \\ E-mail: maria.aluchna@sgh.waw.pl \\ doi:10.13165/IE-13-7-2-04
}

\begin{abstract}
Transition process had a significant impact on the corporate governance in Poland leading to the emergence of new control patterns and institutions. The transition changed the characteristics of shareholder structure of companies shifting ownership from public to private hands. The implemented reforms not only led to privatization of state owned enterprises, but also contributed to the development of newly founded companies. Currently, companies set up after 1989 constitute a dominant group of listed companies' population depicting their specific corporate governance characteristics. These companies reveal ownership concentration and are often controlled by founders adopting pyramidal structures. The article presents the phenomenon of pyramidal structures discussing the ownership structure of Polish listed companies. It also illustrates the issues with data as well as short presentation of case studies of three founder's controlled companies, which use pyramids and reveal strong control by their founders.
\end{abstract}

JEL classification: M13, P20.

Keywords: pyramidal structures, founder control, concentrated ownership, corporate governance, Poland.

Reikšminiai žodžiai: piramidinė struktūra, steigejų kontrolè, koncentruota nuosavybė, Lenkija.

\section{Introduction}

Transition process had a significant impact on the corporate governance in Poland leading to the emergence of new control patterns and institutions. The transition changed the characteristics of shareholder structure of companies shifting ownership from public to private hands. The implemented reforms not only led to the privatization of state owned enterprises, but also contributed to the development of newly founded companies (Dzierżanowski and Tamowicz, 2002; Urbanek, 2009). Currently, companies set up after 1989 constitute a dominant group of listed companies' population depicting their specific corporate governance characteristics. These companies reveal specific corporate governance practices, ownership characteristics and development dynamics. They 
(also in the case of public listed firms) are often controlled by founders, their families or other individuals and adopt pyramidal structures, which allow for lowering capital involvement while assuring for dominating position and strong control over the company (Aluchna, 2013). The article presents the phenomenon of pyramidal structures discussing the ownership structure of listed companies of post transition Poland. The presentation of the ownership changes and the emergence of pyramidal structures amongst listed companies founded after 1989 is based on the analysis of data on ownership structure and the short discussion of three case studies. The case studies present examples of three founder's controlled companies - Getin Noble Bank SA controlled by Leszek Czarnecki, the corporate group of four companies controlled by Michał Sołowow and TVN controlled by families of three founders. All of the analyzed companies use pyramids and reveal strong control by their founders.

The paper aims to present the phenomenon of pyramidal structures adopted in listed companies controlled by their founders relating the issue to the overall changes in ownership structure in Poland as well as the popularity of these structures worldwide. It contributes to a better understanding of corporate governance as well as the dynamics of management and finance in the founder's controlled companies. With the strong control over the company, the founders assure for the optimal use of capital and make quick decision on restructuring and changes in corporate strategies. All of the three analyzed companies engaged in the significant restructuring and reorganization process and the decision on mergers, acquisitions and spin offs where undertaken and implemented fast and smoothly. The significant control of founders may, however, affect the position and rights of minority shareholders, who require the dialogue and equal treatment. The paper is organized as follows: in Section 1, the changes in ownership as the result of the transition process in Poland are presented. Section 2 delivers the analysis on the ownership structure of Polish companies as well as presents the concept of pyramidal structures, their characteristics and logic behind their functioning. In Section 3, the case studies of three Polish founder's controlled companies, which reveal strong ownership concentration and adoption of pyramidal structures, are discussed. Final remarks are presented in the Conclusion section.

\section{Ownership shift as the main goal of transition in Poland}

The transition in Poland, which started in 1989, aimed at the system change from socialism to democracy and from centrally planned to market economy (Myhalyi, 1997). The scope and the complexity of the change were viewed as unprecedented in both economic and political dimensions. Polish economy faced the lack of private ownership and its economic system was referred to the so called "destroyed capitalism" (Balcerowicz, 1995), characterized by the dominance of conglomerates, heavy industry and lack of competition, whereas many companies were in serious financial distress (known as 'value subtractors'). From the perspective of economic reforms, two types of reforms were viewed as crucial elements of the process (Svejnar, 2001; Balcerowicz, 1995). Type I reforms related to the macroeconomic stabilization, price liberalization, the reduction of direct subsidies, the breakup of trusts, state-owned enterprises and the mono-bank system, the removal of barriers to 
the creation of new firms, carrying out small-scale privatization and the introduction of a social safety net. The exposure to the international economy, especially to the international trade, induced a more efficient resource allocation. Type II reforms referred to rebuilding institutional framework, large-scale privatization, the development of a commercial banking sector and effective tax system, labor market regulations and institutions related to the social safety net and establishment and enforcement of a market-oriented legal system and accompanying institutions. These reforms appear to be essential from the perspective of the development of institutional order and framework for companies' operation. It is crucial to emphasize that only the evolvement of adequate governance framework would reinforce the reform effort and provide efficient environment for further development (Frydman et al., 2000; Berglof, 1999). The transition process was complex and complicated due to the social pressure and high expectations, the lack of capital and insufficient knowledge and experience of managers and financial analysts (Frydman and Rapaczynski, 1996). More importantly, the regulatory functions previously fulfilled by the state must have been taken over by institutions of private property, set of institutions ensuring enforceable allocation of responsibility (commercial codes, collateral, bankruptcy), institutions that control and monitor the behavior of these, who hold the property of others (banking regulators, stock markets, security regulators) (Murrell, 2000). However, the problems and challenges of the transition process are beyond the scope of the paper, as the main focus is the ownership change and the development of companies founded after 1989.

The privatization schemes as well as the development of new institutional order undertaken after 1989 were aimed at the creation of a new structure of agent-principal relations, control and decision making rights allocation, and enhanced efficiency of the economy (Mc-Dermott, 2000). The privatization process covered a set of different schemes, including direct and indirect privatization (mostly via case by case sale), liquidation, mass privatization program as well as marginal cases of management buyouts and employee stock ownership plans (Kozarzewski, 2003). The second element of the process - the development of new institutional order - was supported by the emergence of market economy institutions, banking reforms and enforcement of new law, which should support the foundation and development of new companies. The experience of the transition process, including changes in politics, rebuilding institutional order, developing corporate governance implementing privatization schemes, is shared by a majority of Central and East European countries, which belonged to the so called Soviet block. Currently, the different paths of reforms and programs reveal the effectiveness of the adopted solutions and may serve as a platform for comparison and exchange of this unique experience. The analysis of the corporate governance development in Central and East European countries indicate differences in the transition agenda, which led to the emergence of various strengths and challenges of today. Additionally, studies in the development of corporate governance systems and structures allow understanding the emergence and effectiveness of regulations and the slow pace of the creation and the complexity of the institutional order.

The reports on the ownership changes in Poland reveal the constant progress in the privatization of former state owned enterprises, transformation of which illustrates the path of reforms and restructuring of the economy (Bornstein, 2000; Estrin, 2000). However, the characteristics of the Polish corporate governance correspond with the fea- 
tures identified by Berglöf and Claessens (2006) for transition and emerging markets. These economies reveal that the crucial control role is played by the internal mechanisms, whereas the monitoring function of external mechanisms (stock market, market for corporate control, reputation) is significantly weaker. The similar characteristics are to be found in Polish corporate governance system, where dominant and/ or controlling shareholder of different identity play a crucial role in the ownership structure and control the process of board directors' appointment. The remaining elements of corporate governance in Poland refer to the two tier board model, insufficient investor protection and ineffective legal system. However, the initiative of the code of best practice significantly improved the standards of corporate disclosure. From the perspective of the structural changes and the development of the overall economy, the emergence of newly founded companies appears to be the real test for the transition process. The foundation of new companies supports the changes in the institutional framework and corporate governance as well as determines the economic growth. The studies show the surge in the emergence and growth of newly founded companies, which is supported by the development of the stock market and its alternative OTC segment. The strongest growth was observed after Poland's succession to the European Union, however, currently the process has weakened due to the economic slowdown.

\section{Ownership of companies in post transition Poland}

\subsection{The general characteristics}

The transition process led to dramatic changes with respect to the patterns of ownership and control of Polish companies. The recent research has not only illustrated the path of these changes, but also revealed significant dynamics in terms of the ownership characteristics. Referring only to publicly listed companies, the ownership analysis takes into account companies of various origins:

- companies privatized via listing on the stock market with still the largest stake owned by the state;

- companies privatized via case by case sale to the foreign strategic (industry) investor;

- companies privatized and currently controlled by domestic strategic investors;

- companies privatized or newly founded and currently controlled by the financial investor;

- companies revealing relatively dispersed ownership;

- companies which went through the mass privatization program;

- companies founded after 1989 and controlled by the founder, the founder's family or other individual investor.

The analysis of the ownership structure of Polish companies seems to support the studies by Berglöf and Claessnes (2006), who point at the ownership concentration and control, executed by the majority shareholder as one of the most important features of 
transition and emerging markets. The ownership concentration characterized by the average majority shareholder stake estimated at $41 \%$ shares (Kozarzewski, 2003; Aluchna, 2007; Urbanek, 2009), which limits the number of shareholders in the company's ownership structure and affects the free float. The ownership concentration is usually rooted in the specificity of Polish economy and associated with the post transition reforms, emerging market characteristics, continental Europe origin and influence of the civil law (Coffee, 1999). Interestingly, the ownership concentration remains a relatively stable feature of Polish listed companies observed within the last 23 years after the transition started (Dzierżanowski and Tamowicz, 2002). The analysis of the shareholder identity of Polish listed companies is presented in Table 1 below.

Table 1. Ownership structure of Polish companies (no. of sample companies, \% of sample companies)

\begin{tabular}{|l|c|c|c|c|}
\hline \multicolumn{1}{|c|}{ Shareholder category } & $\mathbf{1}^{\text {st }}$ largest & $\mathbf{2}^{\text {nd }}$ largest & $\mathbf{3}^{\text {rd }}$ largest & $\mathbf{4}^{\text {th }}$ largest \\
\hline Executives & $88(25.1 \%)$ & $49(17.3 \%)$ & $31(15.3 \%)$ & $18(14.5 \%)$ \\
\hline Supervisory board directors & $39(11.4 \%)$ & $40(14.1 \%)$ & $28(13.8 \%)$ & $12(9.7 \%)$ \\
\hline Other individual & $24(7.1 \%)$ & $24(8.5 \%)$ & $25(12.3 \%)$ & $13(10.5 \%)$ \\
\hline Strategic foreign investor & $60(17.1 \%)$ & $18(6.4 \%)$ & $8(3.9 \%)$ & $5(4.0 \%)$ \\
\hline Financial foreign investor & $6(1.7 \%)$ & $14(4.9 \%)$ & $9(4.4 \%)$ & $5(4.0 \%)$ \\
\hline Strategic domestic investor & $71(20.3 \%)$ & $26(9.2 \%)$ & $16(7.9 \%)$ & $6(4.8 \%)$ \\
\hline Financial domestic investor & $28(8.0 \%)$ & $66(23.3 \%)$ & $47(23.2 \%)$ & $42(33.9 \%)$ \\
\hline NIF & $4(1.1 \%)$ & $2(0.7 \%)$ & - & - \\
\hline Pension fund & $7(2.0 \%)$ & $36(12.7 \%)$ & $35(17.2 \%)$ & $20(16.1 \%)$ \\
\hline State & $14(4.0 \%)$ & $4(1.4 \%)$ & $1(0.5 \%)$ & $1(0.8 \%)$ \\
\hline $\begin{array}{l}\text { Cross shareholding } \\
\text { (to be liquidated) }\end{array}$ & $4(1.1 \%)$ & $4(1.4 \%)$ & $3(1.5 \%)$ & $2(1.6 \%)$ \\
\hline Dispersed ownership & $7(2.0 \%)$ & - & - & - \\
\hline Total & $350(100 \%)$ & $283(100 \%)$ & $203(100 \%)$ & $124(100 \%)$ \\
\hline
\end{tabular}

Source: compilation based on Urbanek, 2009, p. 392-393.

The first analysis of shareholder's identity of Polish companies indicated the dominant presence of strategic (industry) investors, both of foreign and domestic origin, which is tied to the privatization schemes (Dzierżanowski and Tamowicz, 2002). Over the years, however, the emergence and development of companies set up after 1989 led to the growth in the position of founders as the most frequent shareholder category, which is shown in Table 1 . The surge of domestic individual investors as the most frequent majority shareholders of Polish listed companies is perceived as the recent phenomenon and is related to the development of newly founded companies. Over the last years, founders have overtaken the strategic (industry) investors as the most frequent type of shareholders in Polish listed companies. The individual investors often combine the role of majority shareholders (playing key roles via their representatives in the supervisory board) and the role of executives at the management board. Therefore, they may combine ownership and control exerting decision making and supervision over the company. 


\subsection{Pyramidal structures as mechanisms for concentrating ownership}

Recently, the phenomenon of significant ownership concentration of Polish companies has been additionally associated with the adoption of pyramidal structures. The pyramidal structures are the mechanism for increasing control, usually used in companies characterized by the ownership concentration, involvement of families or financial and industrial companies as well as accompanied by the adoption of preferred shares (Morck, 2005; Bebchuck, 1999). Pyramidal structures are the ownership type constituting of multi level companies with cross shareholdings, which form relations of control (Zattoni, 1998; Bennedsen and Nielsen, 2006). Via the controlling (holding) company, the dominant shareholder exerts control and influence on decision making and profit distribution over all the portfolio companies, out of which many may be listed (Cuervo-Cazzura, 2006). The main listed company is located at the apex of the pyramid and is controlled via the chain of subsidiaries, many of which do not report any operational activity, but serve as financial and holding vehicles. The model of a pyramid in three different versions is presented in Figure 1.

Figure 1: The model of a pyramid

a) One direction cross shareholdings, one level pyramid

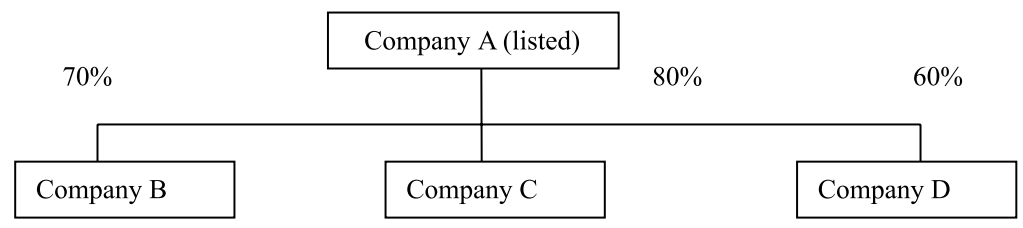

b) One direction cross shareholdings, two level pyramid

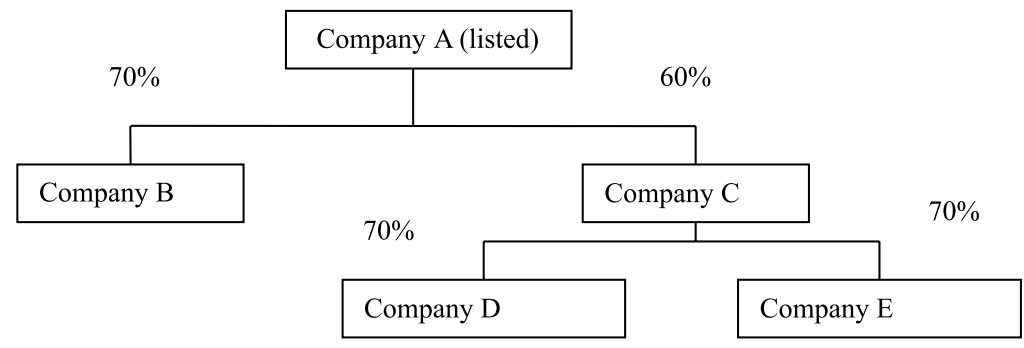

c) Multi direction cross shareholdings, two level pyramid

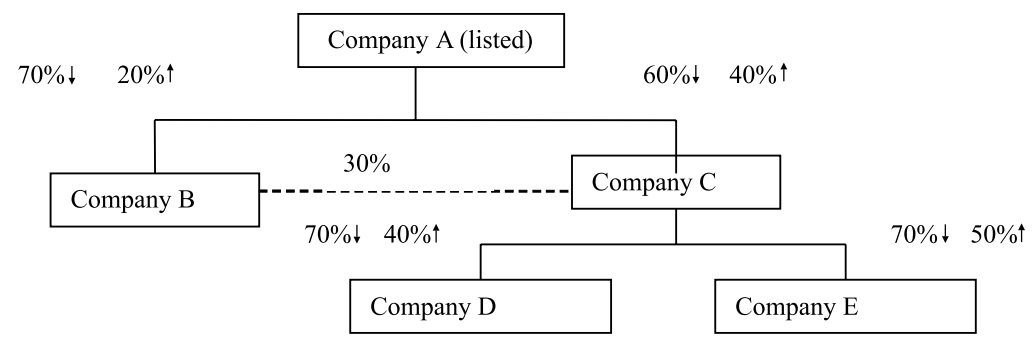

Source: own compilation. 
As it is shown in Figure 1, the pyramidal structure has a set of characteristic features. First, the pyramid is composed of several levels. Although there are only maximum 2 levels of ownership in the model, the analysis shows that the number of the levels in the pyramid may be as large as 14 (Morck, 2009). Second, the ownership structure may seem dispersed, but, as a matter of fact, due to many cross shareholdings and ownership ties between different shareholders, it is concentrated. Third, the controlling shareholder is present at different levels and different elements of the pyramid - he or she may control minority stakes, but in reality has the controlling position over the company. Finally, the model in Figure 1a is very simple and it assumes that the ownership is hierarchical - there may be, however, many mutual links between e.g. Companies B and $\mathrm{C}$ and $\mathrm{E}$, as it is presented in Figure 1c. Additionally, the ownership links may be mutual - i.e. company B has stakes in Company A and Company A also has stakes in Company B. Such patterns are legally prohibited in Poland, but are very popular e.g. in South Korea. Model shown in Figure 2 reveals the pyramidal ownership, where an individual investor (founder) has the controlling position and is present in different companies on different levels throughout the pyramid.

Figure 2: The model of a pyramid controlled by an individual investor

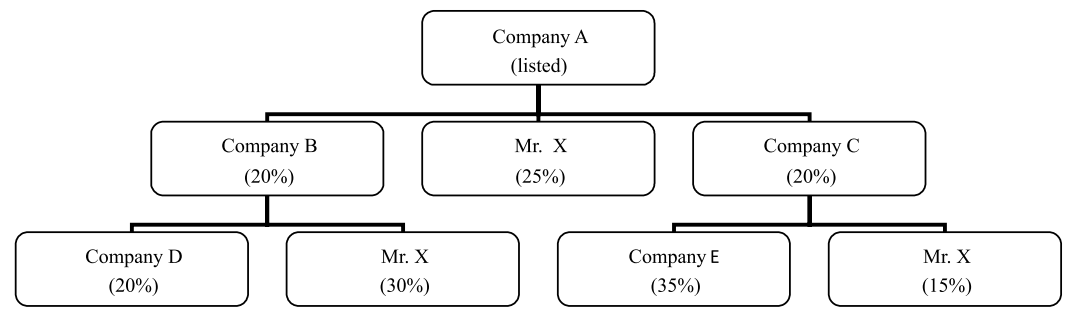

Source: own compilation.

The pyramidal structures are very popular worldwide. They are depicted in line of the comparative analysis of emerging markets, which are revealed in India, South Korea, Thailand, Russia, the Ukraine, Latin American countries (mostly researched - Mexico, Brazil, Chile, Peru, Argentina). Interestingly, the pyramidal structures are also to be found in developed economies, such as Canada, Belgium, Italy, France, Sweden (Morck, 2005). It is, however, important to mention that the pyramidal structures may lead to the unequal treatment of shareholder, the abuse of minority shareholders and the realization of private benefits by the controlling investors via tunneling, related party transaction, dividend payouts, etc. (Zattoni, 1999).

\section{Pyramidal structures in Poland - case studies}

The research on the pyramids in Poland are extremely scarce, as the phenomenon has been discovered very recently and due to the constraints revealed to the lack of the 
detailed data on the ownership structure of the companies. The very few studies on the pyramids reveal that:

- the pyramids are very popular, as they are adopted by ca. $70 \%$ of listed companies; the pyramids are mostly adopted by strategic investors and founders; the pyramids are non existent in companies controlled by the state.

In order to illustrate the characteristics and the idea of functioning of Polish pyramids, three case studies are discussed below. All of these cases refer to the companies set up after 1989, which are controlled by the founders.

Leszek Czarnecki is a well known Polish entrepreneur, involved in the financial sector. He founded and currently controls a financial conglomerate. The conglomerate underwent a significant restructuring in 2011, which led to the split of one unit into two corporate groups (Getin Holding SA and Getin Noble Bank SA). Both groups encompass a number of companies, many of which are listed on the stock exchange, and still note strong dynamics of growth and structural changes. Czarnecki directly controls stake of over 55\% in Getin Holding SA, the vehicle focused on entrepreneurial projects of higher risk and higher potential for growth. He also indirectly controls Getin Noble Bank SA via his company known as Get Bank (93\%), which is again controlled indirectly (42\%) and directly (10\%) by his company LC Corp. The control over the companies in the group allows for the optimal use of capital, financing new ventures and projects as well as fast restructuring (spin offs, mergers and acquisitions).

Michał Sołowow is a well known Polish entrepreneur, involved in the construction sector. He founded and currently controls four companies listed on the Warsaw Stock Exchange. His group includes Barlinek SA, operating in housing equipment materials and producing wooden floors, which is controlled by Mr. Sołowow via his company Barcocapital Investment Ltd. (69\%). The second company is Cersanit SA, operating in ceramic sector, which is controlled by Mr. Sołowow indirectly and directly (the combined stake of $49 \%$ ). The next company is the group called Echo Investment SA, a construction firm specializing both in residential and commercial housing - Mr. Sołowow controls Echo Investment via the subsidiary Beva-Hold Ltd. (40.45\%). Finally, the fourth company is Synthos SA, operating in the rubber sector, which is controlled by Mr. Sołowow via two subsidiaries of Magellan Pro-Equity Fund I SA (57\%). All these four companies construct their respective capital groups of several firms. Similarly to the corporate group of Leszek Czarnecki, the control over the companies in the group allows for the optimal use of capital, financing new ventures and projects as well as fast restructuring (spin offs, mergers and acquisitions).

TVN SA is the largest Polish private media company listed on the Warsaw Stock Exchange, founded and controlled by three entrepreneurs - Maciej Walter, Jan Wejchert (who passed away in 2009) and Bruno Valsangiacomo. The control is exerted by the founders indirectly via two companies, the Polish Television Holding SA (53\%) and Cadizin Trading \& Investment (3\%), which construct a classical pyramidal structure. TVN SA and its founders are known for their tendency to a number of related party transactions. The new ventures followed the path of full control by ITI, the owner of the Polish Television Holding SA, and, while being developed, were sold within the group directly to TVN and its minority shareholders. The corporate group encompassing ca. 20 firms has faced significant changes within the last three years. The quick decisions of res- 
tructuring and spin offs as well as joint ventures and changes in the ownership structure were possible due to the full control by the three founders and their families.

As it is shown in the short presentation of the three case studies, Polish companies set up after 1989 and controlled by the founders reveal strong ownership concentration and control exerted by the adoption of the pyramidal structures. In the discussed case studies, the founders control the listed companies directly owing a stake and indirectly via their subsidiaries or financial vehicles. Hence, they tend to lower their capital investment yet maintaining the control over the company, even when it is listed on the stock exchange. Such ownership patterns provide for the control over the development of the companies, it allows for the optimal use of capital, financing new ventures and projects as well as fast restructuring. During the last three years, all the discussed corporate groups have undergone significant changes and restructuring and engaged in projects of spin offs, mergers and acquisitions. These transactions - although in all three cases discussed and criticized by a minority shareholder, who felt abused - led to the fast reorganization of the companies and help to develop significantly.

\section{Conclusion}

The transition reforms in Poland had a significant impact on the development of corporate governance and the changes of the ownership structure of the companies. In line with the transition and the development of market economy, newly founded companies emerged revealing their specific shareholder structure and managerial characteristics. As it has been discussed in the paper, the surge of domestic individual investors as the most frequent majority shareholders of Polish listed companies is perceived as the recent phenomenon. Over the last years, founders have overtaken the strategic (industry) investors as the most frequent type of shareholders in Polish listed companies. The analysis of founder's controlled firms depicts significant ownership concentration and the use of the pyramidal structures, which allow for lowering capital involvement, while assuring for the dominating position and strong control over the company. The use of the pyramidal structure appears to be very frequent in Poland. The presented three case studies illustrate the phenomenon of the pyramids and the founders' control in companies set up after 1989. Although such ownership structure is often criticized by minority shareholders, as it may lead to the abuse of their interest, it undoubtedly allows the founder's controlled companies to undertake fast restructuring process and to immediately react to market changes.

\section{References}

1. Aluchna, M. Piramidal Structures in Poland. Organizacja i Kierowanie. 2013, forthcoming.

2. Balcerowicz, L. Polskie Reformy Gospodarcze [Economic Reforms in Poland]. Warszawa: Polskie Wydawnictwo Naukowe, 1995. 
3. Bebchuk, L.A.; Kraakman, R. and Trantis, G. Stock Pyramids, Cross Ownership and Dual Class Equity: The Mechanisms and Agency Costs of Separating Control from Cash Flow Rights. Harvard Law School Olin Discussion Paper. 1999, 249.

4. Bennedsen, M. and Nielsen, K. The Principle of Proportional Ownership, Investors Protection and Firm Value in Western Europe. ECGI Working Paper. 2006, 134.

5. Berglof, E. Reforming Corporate Governance: Redirecting the European Agenda, in: Cohen, S. S. and Boyd, G. (Hgs.). Corporate Governance and Globalization. Long Range Planning Issues. Northampton, USA: Edward Elgar, 2000.

6. Berglöf, E. and Claessens, S. Enforcement and Good Corporate Governance in Developing Countries and Transition Economies. World Bank Research Observer. $2006(21,1):$ 123-150.

7. Bornstein, M. Post-Privatization Enterprise Restructuring. William Davidson Working Paper. 2000, 327 [interactive]. [accessed on 08-012013]. <http://eres.bus. umich.edu/docs/workpap-dav/wp327.pdf>.

8. Coffee, J. Privatization and Corporate Governance: The Lessons from Securities Market Failure. Columbia Law School, Center for Law and Economics Studies. Working Paper. 1999, 158 [interactive]. [accessed on 10-01-2013]. <http://www2. law.columbia.edu/law-economicstudies/papers/workp158.pdf >.

9. Cuervo-Cazzura, A. Business Groups and Their Types. Asia Pacific Journal of Management. 2006 (23): 419-437.

10. Dzierżanowski, P. and Tamowicz, P. Ownership and Control of Polish Listed Corporations. 2002 [interactive]. [accessed on 08-01-2013]. <http://ssrn.com/paper $=386822>$.

11. Estrin, S. Competition and Corporate Governance in Transition. William Davidson Working Paper. 2001, 431 [interactive]. [accessed on 10-01-2013]. <http://eres.bus. umich.edu/docs/workpap-dav/wp431.pdf>.

12. Frydman, R.; Gray, Ch.; Hessel, M. and Rapaczynski, A. The Limits of Discipline. Economics of Transition. 2000 (8): 577-601.

13. Frydman, R. and Rapaczynski, A. Overview of Volumes 1 and 2, in: Frydman, R.; Gray, Ch. W. and Rapaczynki, A. (Hgs.). Corporate Governance in Central Europe and Russia. 1996 (1): 1-19.

14. Kozarzewski, P. Corporate Governance and Secondary Privatization in Poland: Legal Framework and Changes in Ownership Structure. CASE Network Studies and Analyses. 2003, 263 [interactive]. [accessed on 08-01-2013]. <http://ssrn.com/abstract $=1443803>$.

15. Mc-Dermott, G. Network Restructuring and Firm Creation in East-Central Europe: A Public-Private Venture. William Davidson Working Paper. 2000, 361 [interactive]. [accessed on 08-01-2013]. <http://eres.bus.umich.edu/docs/workpap-dav/wp361.pdf>.

16. Mihalyi, P. Corporate Governance during and after Privatization: The Lessons from Hungary. F.I.T. Discussion Paper. 1997, $17 / 97$.

17. Morck, R. A History of Corporate Governance Around the World: Family Business Groups to Professional Managers. Chicago: University of Chicago Press, 2005.

18. Morck, R. The Riddle of the Great Pyramids. National Bureau of Economic Research, Working Paper. 2009, 14858. 
19. Murrell, P. Evolution in Economics and in the Economic Reform of the Centrally Planned Economics, in: Clauge, C. C. and Rausser, G. (eds.). The Emergence of Market Economies in Eastern Europe. Blackwell: Cambridge, 1992 [interactive]. [accessed on 08-01-2013]. <http://www.bsos.umd.edu/econ/murrell/papers/czep.html >.

20. Svejnar, J. Transition Economies: Performance and Challenges. William Davidson Working Paper. 2001, 415 [interactive]. [accessed on 10-01-2013]. <http://eres.bus. umich.edu/docs/workpap-dav/wp415.pdf >.

21. Urbanek, P. Struktura Własności i Kontroli w Polskich Spółkach Publicznych w Warunkach Kryzysu Gospodarczego [Ownership and Control of Polish Listed Companies at the Times of Economic Crisis]. Nadzór Korporacyjny a Przedsiębiorstwo, Gdańsk University Working Papers. 2009 (1): 383-398.

22. Zattoni, A. The Structure of Corporate Groups: The Italian Case. Corporate Governance. 1999, 1(7): 38-48.

Maria Aluchna works as Associate Professor at the Department of Management Theory, Warsaw School of Economics. She specializes in corporate governance (ownership structure, board, executive compensation, transition economies) as well as in strategic management and corporate social responsibility.

\section{SOCIALINE் VERSLO ATSAKOMYBE் STEIGĖJŲ KONTROLIUOJAMOSE KOMPANIJOSE}

Santrauka. Pereinamuoju laikotarpiu atsiradusios naujos kontrolès formos ir institucijos turejo didelę ịtaką socialinei verslo atsakomybei Lenkijoje. Šiuo laikotarpiu pasikeite kompanijų akcininkų struktūra, valstybės nuosavybè perèjo privatiems savininkams. Igyvendinant reformas ne tik buvo privatizuotos valstybès valdomos įmonès, bet ir steigiama daug naujų kompanijų. Šiuo metu kompanijos, ịsteigtos po 1989 m., sudaro dominuojančią listinguojamų kompanijų dalį. Šios kompanijos pasižymi ir specifinèmis socialinès verslo atsakomybès formomis. Šioms kompanijoms būdinga privataus kapitalo koncentracija ir jos dažnai kontrolipuojamos jų steigejų, pritaikant piramidinę struktūrą.

Straipsnyje pristatomas piramidinès struktūros fenomenas ir aptariama Lenkijos listinguojamų kompanijų nuosavybės struktūra. Aptariami klausimai iliustruojami duomenimis ir trijų steigèjų kontroliuojamų kompanijų, pritaikiusių piramidines struktūras, atvejų analizès pavyzdžiais.

Maria ALUCHNA - Ph.D., Associate Professor, Department of Management Theory, Warsaw School of Economics Research Fields: corporate governance, corporate social responsibility, strategic management.

Maria ALUCHNA - Varšuvos ekonomikos mokyklos Vadybos teorijos katedros docente, mokslų daktarè. Mokslinių tyrimų sritys: įmonių valdymas, įmonių socialinė atsakomybė, strateginis valdymas. 